\title{
ULAMA PEREMPUAN DAN DEKONSTRUKSI FIQIH PATRIARKIS
}

\author{
Yayuk Fauziyah*
}

\begin{abstract}
In the historiography of Idam femaleulama did not as yet reeive a suffient attention fromboth the historians and themasses It is this unfortunatething that this paper is concemed with It traces theorign of thismarginalization-asit were andfinds at that all thisisduetothedomination of maleulamainthewhdehistary of Isamicthought. Whilethis dominationmight beacceptablefor some, theurfortunatethingis that themaleulamain thir turn will offer the patriarchal interpreation of Idamotten at the expenses of nomen. This paper dellenges this form of interpreation and calls for the necessity of methodblogical deenstruction tovard a better andmmehumaneundestanding of Idam It supports theefforts of MuhammadArkan whosecritical mothod fouses on far stages of analysis in rdation to theinterpreation of religias text. Thesearehistorical analysis anthropdogical, soidogical andlinguisticanalysis Thefirst threearecontextual whilethefourthistextual. Initsanalysis, thepaperemploysanapproadh that representsa saundandacceptablebalancebdween patriarchy and matriardy. It bediees that gendar-based prgudices must beeradicated if wearetoproduce enlightened discarses of religion

Keywords: gender, femaleulama, patriardy, matriardy
\end{abstract}

\section{Pendahuluan}

Kerisauan banyak kalangan terhadap 'kelangkaan ulama'1 di Indonesia khususnya disinyalir karena konstruksi religio-sosiologis yang menitikberatkan pada konsep ulama yang bisa dibilang terlalu ekstrim; yaitu orang yang ahli dalam bidang ilmu agama atau fiqh Namun dalam konteks Indonesia, keahlian dalam bidang fiqhsaja belum cukup bagi seseorang untuk diakui sebagai ulama. Terdapat orang-orang di Indonesia yang ahli dalam bidang ini tapi belum dipandang masyarakat luas sebagai ulama. Malah mereka yang intens terlibat dalam kegiatan religio-sosioal seperti pengajian, majelis talim sampai kepada pemberian do'a restu justru disebut ulama. Sering terlihat juga orang yang tidak seberapa ilmunya tetapi dipandang ulama karena punya pesantren.

Bagi perempuan tidak mudah -bahkan mustahil- menyandang status sebagai ulama. Perempuan dalam perjalananya termarginalisasi oleh kaum laki-laki yang menganggap dirinya superior atas kaum wanita. A kibat konstruksi religio-sosiologis yang berdalih teologis, banyak yang menganggap bahwa perempuan itu sub ordinat dari kaum laki-laki. ${ }^{2}$ Kontroversi

* Universitas Muhammadiyah Jember, Jawa Timur.

${ }^{1}$ Kelangkaan ulama dalam arti sempit juga diakui oleh Nakamura. Lihat Mitsuo Nakamura," Muhammadiyah: Gerakan Islam Yang Kokoh", wawancara dalam MediaInoxasi, No. 11, Tahun VI, D esember 1994.

${ }^{2}$ Persepsi tersebut disebabkan oleh dua faktor. Faktor ilmiah dan faktor non ilmiah. Adapun faktor non ilmiah yang meliputi pemahaman keagamaan dan tradisi masyarakat. Faktornon ilmiah yang berkaitan dengan pemahaman keagamaan. Sebagian besar masyarakat beragama masih berkeyakinan bahwa perempuan lahir ke dunia dipandang sebagai makhuk yang lemah, yang serba kekurangan. Perempuan diciptakan kurang akal dan kurang agama. Apabila pemahaman keagamaan tersebut benar dan dapat dipertanggungjawabkan, sangat wajar apabila laki-laki lebih cerdas daripada perempuan. Akan tetapi, pemahaman keagamaan tersebut dáif(lemah) dan tidak dapat dijadikan sebagai hlijah(argumentasi). Faktor non ilmiah kedua berkaitan dengan tradisi masyarakat. Didalam masyarakat paternalistik yang sangat maledominated(perempuan dianggap sebagai seondgenderyaitu masyarakat 
mengenai posisi dan peran kepemimpinan atau ulama perempuan sering pula dihadirkan dalam ranah fiqh Secara umum, pemahaman fiqhyang berlaku dalam kehidupan sehari-hari masih bersifat patriarki. Kentalnya budaya kebapakan dalam tradisi penciptaan fiqh menjadikan penetapan hukum Islam kurang mendefinisikan kemitraan perempuan dengan laki-laki. Sehingga citra perempuan yang muncul hanya sebagai simbol kesucian Ibu yang mengayomi atau simbul kesetiaan. Jarang perempuan disimbulkan dengan penguasa, hakim, ulama, pejuang dan pemegang karier lainnya. ${ }^{3} \mathrm{Hal}$ ini tentunya berseberangan dengan semangat al-Q ur'an yang mengakomodasi pemberian hak dan status yang menguntungkan bagi perempuan. Oleh karena itu untuk menjawab permasalahan tersebut penulis ingin mengokohkan justifikasi terhadap posisi dan peran ulama perempuan dengan melacak kembali eksistensi ulama perempuan dan mencoba mengungkap kontroversi tentang ulama perempuan di antara kalangan Fuqaha's D an karena ada pemahaman yang bias gender dari Fugaha', maka penulis menawarkan metodologi dekonstruksi figh patriarki untuk menuju kesetaraan gender, di antaranya dengan pendekatan sosio-teologis.

\section{Melacak Historiografi Ulama Perempuan}

Kajian tentang "ulama perempuan" dalam sejarah masih sangat langka, bukan hanya untuk di Indonesia, tetapi juga di wilayah Muslim lainnya. Meski kajian tentang perempuan dan gender terus menemukan momentumnya, namun perhatian hampir tidak pernah diberikan kepada sejarah sosial intelektual ulama perempuan. Asumsi awal yang digenggam banyak peneliti dan sarjana adalah bahwa hal itu merupakan salah satu bukti tentang tidak signifikannya perempuan dalam keulamaan atau bahkan dunia keilmuan umumnya.

Kajian awal Azra tentang ulama perempuan di Timur Tengah mengindikasikan tentang terbatasnya peran ulama perempuan. Bahkan dapat dikatakan, sejarah ulama perempuan itu tidak pernah ada. Sudah maklum bahwa ulama perempuan tidak mendapatkan tempat yang sewajarnya dalam sumber-sumber sejarah historiografi Islam padahal terdapat cukup banyak ulama perempuan yang mempunyai peran-peran penting dalam keulamaan dan keilmuan Islam, sejak hadith fiqh, sampai tasaunuf. Juga terdapat peran-peran krusial dalam pembentukan dan pengembangan lembaga-lembaga pendidikan Islam, seperti madrasah, ribat dll.

kelas dua) . Anggapan tersebut sebagian disebabkan oleh pemahaman keagamaan. Karena perempuan diciptakan dari tulang rusuk laki-laki, perempuan harus dilindungi dan lain-lainnya Di dalam tradisi Jawa, di samping disebut sebagai garva-sigaraningnyawa(belahan jiwa), perempuan sering juga disebut sebagai kancaingwingking (pembantu) dengan peran domestik yang "luhur" masak (memasak ), Macak (berdandan), dan Mamak (melahirkan) atau dah-dah isah-isahdan momongbocahTradisi patemalistik tersebut membuat perempuan tidak memiliki atau tidak mempunyai kesempatan untuk mengembangkan kemampuannya. Hal itu terutama disebabkan karena perempuan kurang mendapat kesempatan pendidikan. Di dalam masyarakat terutama masyarakat pedesaan ada sebuah anggapan bahwa sepandai apapun perempuan akan ke dapur juga. Wonguadonikukayajanitingsampiran atau Wongvadonikukesimptbedbed ketiingkung bengkungJadi orang perempuan itu terbatas sekali ruang lingkupnya. Faktor ilmiah yang meliputi kurangnya data dan salah pengertian tentang hakekat kecerdasan. Banyak data "ilmiah" yang dijadikan sebagai ukuran kecerdasan, seperti jenjang pendidikan, angka buta huruf, indeks prestasi, nilai rapor, dan lain-lain. Tetapi untuk menjelaskan kecerdasan tampaknya sangat relatif dan cenderung tidak akurat, terutama jika kecerdasan dikaitkan dengan prestasi akademik. Banyak perempuan yang meraih indeks prestasi tertinggi di beberapa perguruan tinggi. Lihat Sri Suhandjati Sukri (ed.), PemahamanIslamdanTantangan Keadilan Jender(Yogyakarta: G ama Media, 2002), 47.

${ }^{3}$ Z ubaedi, IdamBeturan danAntarperadaban(Yogyakarta: ARRUZ MADIA, 2007), 224-225. 
Harus diakui, salah satu kesulitan besar dalam upaya merekonstruksi dan menulis sejarah sosial-intelektual ulama perempuan Indonesia adalah langkanya sumber-sumber tertulis tentang mereka. Dalam historiografi Islam Indonesia tidak tersedia gerre literatur yang di Timur Tengah dikenal sebagai tarajïm(sing. tarjamah atau lengkapnya tajjamah alhayat). D alam istilah historiografi di Barat, taraj̈m dikenal sebagai biographical didionaries kamus biografi. D an sebagaimana disimpulkan Petry yang dikutip oleh Azra bahwa gere taraj̈mmerupakan fenomena yang indegious bagi masyarakat terpelajar Muslim ${ }^{4}$. Kitab tarä̈m di Timur Tengah lazimnya disusun berdasarkan lapisan, angkatan atau generasi dalam kurun tertentu atau berdasarkan pengelompokan dalam bidang keahliannya atau profesi tertentu. Karena itu terdapat, misalnya, taraj̈myang merupakan tabacatppara sahabat Nabi muhammad saw atau tabi'in di masa setelah sahabat, dan generasi-generasi sesudahnya mereka pada abad ke abad dan juga terdapat taraj̈mberdasarkan keahlian seperti tabaqateal-furahał, tajbaqat al-mihaddithin atau tabaqat al-shifa'. ${ }^{5}$

Berkaitan dengan ulama, Azra melihat ada perbedaan persepsi ulama di Indonesia dan Timur Tengah. Pengertian ulama cenderung kembali meluas mencakup orang-orang yang ahli dalam ilmu agama dan ilmu-ilmu umum, tetapi di Indonesia umumnya pengertian ulama secara sempit dan terbatas hanya meliputi orang yang ahli dalam bidang ilmu agama atau figh

Akibat penyempitan pengertian di atas tidak mengherankan ada kerisauan di kalangan banyak mayarakat Muslim tentang apa yang mereka sebut sebagai 'kelangkaan ulama'. Penulis lebih mendefinisikan kelangkaan ulama itu sebagai akibat dari penyempitan makna ulama, atau akibat dari konstruksi religio-sosialogis yang memarginalkan perempuan, sehingga terapinya adalah adanya dekonstruksi terhadap fiqh patriarki.

Pusat Penelitian dan Pengkajian Islam dan Masyarakat (PPIM) UIN Syarif Hidayatullah Jakarta telah mengadakan penelitian sampai pada sebuah kesimpulan akan adanya pengkatetgorisasian "ulama perempuan." Hanya saja PPIM tidak mengadopsi istilah ulama dalam pengertian sempit, juga bukan dari pembatasan-pembatasan religio-sosiologis yang dikemukakan di atas. D engan kata lain, pengertian ulama perempuan di sini digunakan dalam pengertian longgar, sehingga hasil pengkategorian sedikit rinci dan longgar dari ulamaulama perempuan yang diakuinya masih tumpang tindih.

\footnotetext{
${ }^{4}$ Tarajïmkhusus tentang perempuan indonesia agaknya baru muncul pada masa kontemporer. Karya yang patut disebut adalah perempuandanilmupengtahuan(1990). Biographical Didionaryyangjuga bisa disebut sebagai Tábaqab al-Mar'ahal-Indurisi fi-gl-'Ilmmerupakan bografi singkat 136 perempuan yang memiliki prominengdalam berbagai disiplin ilmu. Kemudian masih ditambah lagi dengan daftar nama 70 ilmuwan perempuan tanpa uraian biografi sama sekali. Dikatakan Azra bahwa biografi sosial-intelektual ulama perempuan Indonesia ini berbeda banyak dengan Perempuan danIlmuPengtahuan Karena biografi-sosial ulama perempuan mencakup pembahasan yang jauh lebih ekstensif atau tidak hanya sekedar biografi singkat. Lihat Azyumardi Azra, Histariografi, 149, 151. Sedangkan dinamika sejarah sosial-intelektual ulama Indonesia sejak akhir abad ke-60, terutama dengan kemunculan ulama-ulama besar seperti Hamzah Fansuri, Syamsudin al-Sumatrani, Nuruddin al-Raniri, Abd al-Rauf al-Sinkili, dan M. Y usuf al-Muqassari. Tetapi biografi sosial-intelektual ulama-ulama ini direkonstruksi tidaklah berdasarkan tarajim hal ini dikarenakan tidak ada tarajimtentang mereka, melainkan berdasarkan kepingan-kepingan informasi berdasarkan tulisan-tulisan mereka atau catatan orang lain atau riwayat lisan (oral history) yang terus dipelihara masyarakat di mana mereka hidup. Lihat A zyumardi Azra, Historiorafi, 150.

${ }^{5}$ Penulis melihat karya Timur Tengah yang ada korelasinya dengan taraj̈madalah 'A sk bal-Fataxa'; barangkali hanya sebagai perbandinganya adalah Ashbal-Fatakahanya mengungkap ulama masa klasik saja, dan ulama perempuan juga di ungkap. D an sepertinya biografi yang ditulis adalah mulai sahabat. Lihat Ashabbal-Fatawarpenulis lupa dengan pengarangnya).
} 
Adapun kategori tersebut adalah 1) ulama kampus yang mencakup Rahmah El-Yunusiyah, Zakiah D arajat, Bararah Baried, Tuty Alawiyah. 2) ulama pesantren mencakup Sholihah Wahid Hasyim, Hj. Chamamah, Hj. Nonoh Hasanah juga Suryani Thahir. 3) ulama organisasi sosial-keagamaan yang mencakup Nyai Ahmad Dahlan, Bararah Baried, Sinta Nuriyah, 'Aisyah Amini. 4) ulama tabligh (bi al-lisan dan dengan seni) mencakup Lutfiyah Sungkar dan Rafiqah D arto Wahab. ${ }^{6}$

\section{Posisi dan Peran Ulama Perempuan}

Di zaman Rasulullah saw, kaum perempuan sudah berperan dalam berbagai macam aspek pekerjaan. Terutama aspek pendidikan atau memberi fatwa> Ummahat al-múminin, Aishahmempersilahkan kepada orang yang ingin mendalami sunnah Rasulullah saw. Bahkan sebagian mereka turut serta dalam jihad di jalan Allah dan ikut berperang yang dipimpin oleh Rasulullah saw. Misalnya, Nasibbah bint. Ka'ab ikut serta dalam perang Uhıld, Aminah bint. Q aysh al-G hifariyah dan Ablat Bila' K husna ikut dalam perang K haybar, Ummu 'A tivah al-Ansłriyah dan al-Rabi'ah bint. Mas'ud yang ikut dalam peperangan lainnya. ${ }^{7}$ Pada masa Kalifah-pun perempuan memiliki peran penting. Umar bin al-Khattgab mengangkat al-Shifa' bint. Abdillah sebagai pengawas keuangan yang merupakan tugas penting bagi negara.

Peran perempuan khususnya dalam memberi fatwa>ini sudah teraplikasi pada zaman Rasulullah saw. D an menurut penulis peran memberi fatwa`ini bisa diqiyaskan salah satu di antara peran Ulama. Untuk lebih jelasnya, penulis akan menjelaskan beberapa pengertian "ulama" menurut persepsi yang berbeda-beda.

Secara etimologi ulama berasal dari kata 'alimayalamt'ilman (orang yang memiliki ilmu yang mendalam, luas dan mantap). Di dalam al-Q ur'an terdapat dua kata ulama yaitu pada surat Fats ayat 28 dan surat al-Shu'aras ayat 197. Sedang secara terminologis ulama berarti:

Petama, menurut Muhammad Nawawiælari Tanahara Banten Jawa Barat dalam Sharah Asma'>al-Hrsmałlan Sayyid Q uth dalam tafsirnya Fi al-Zilabal-Qur'an (jilid VI juz xxii:130): ulama adalah hamba Allah yang memiliki jiwa dan kekuatan 'khadhyatullah', mengenal Allah dengan pengertian yang hakiki, pewaris Nabi, pelita ummat dengan ilmu dan bimbingannya, menjadi pemimpin dan panutan yang uswah hamah dalam ketaqwaan dan istiqamah yang menjadi landasan baginya dalam beribadah dan beramal shaleh selalu benar dan adil. Sebagai mujahid dalam menegakkan kebenaran, tidak takut pada celaan dan tidak mengikuti hawa nafsu, menyuruh yang ma'ruf dan mencegah pada yang munkar. ${ }^{8}$

Keelua, menurut Horikoshi ulama adalah sekelompok sarjana hukum Islam yang secara tradisional berfungsi sebagai muballigh, guru dan tempat bertanya umat Islam dan khalifah Secara teoritis peranan mereka sebagai ahli hukum Islam ortodoksi menjamin praktek-praktek keagamaan para penganut dan persoalan-persoalan kenegaraan sesuai dengan shari'ah Islam. D alam kehidupan masyarakat lokal, wilayah kekuasaan ulama biasanya dibatasi pada lembaga-lembaga Islam semacam masjid dan madrasah, di mana mereka mengabdi sebagai

${ }^{6}$ Azyumardi Azra, Historiografi, 156.

7Muhammad Anis Q asim Ja'far, Perempuan dan Kdkuasaan: Mendususri Hal Paitik dan Pesscalan dalamIsam terj. (Amzah: 2002), 20.

${ }^{8} \mathrm{Abd}$ Kadir Jaelani, PeranUlamadanSantri dalamPerjuanganPditik Idamdi Indonesia(Surabaya: Bina Ilmu, 1994), 4. 
fungsionaris agama ${ }^{9}$

Ketiga, menurut Ibn al-Jawzi>ulama adalah orang yang berilmu dengan segala disiplin ilmunya, seperti para Qañ', ahli Hadith ahli Fiqh ahli al-ứaz),dan ahli al-Qisas)(para penasehat dan penutur kisah), ahli al-Lughah dan para al-Shuara' ${ }^{\prime 0}$

Keempat, ulama menurut al-G hazali>adalah ada dua yaitu ulama dunia dan ulama akhirat. Ulama dunia adalah ulama yang orientasi keilmuannya tertuju pada kenikmatan dunia, yaitu untuk mencapai kedudukan dan jabatan (ulama' al-Sư). Sedangkan ulama akhirat (ulama' ghyr al-su’) adalah 1) tidak mencari ilmu dengan tujuan untuk mendaptkan harta kekayaan dunia. 2) berbuat sejalan dengan apa yang didakwakan, ulama tidak menyuruh kecuali dia orang pertama yang telah mengerjakan. 3) orientasi keilmuanya adalah ilmu yang bermanfaat untuk kehidupan akhirat. 4) tidak condong pada kenikmatan makanan dan minuman, kesenangan pakaian, dan gemerlapanya tempat tinggal. 5) menjauhi dengan penguasa. 6) berhati-hati dalam memberikan fatwa. 7) perhatian ilmunya lebih pada ilmu batin dan ilmu akhirat. 8) menjadikan kekuatan keyakinan sebagai modal utama dan pertama dalam mencapai tujuan. 9) menampilkan prilaku yang rendah hati dan menghiasi diri dengan lima sifat: khashyah khushư, tamadur, hlesn al-khuluq dan zuhud ${ }^{11}$

Kdima, ulama menurut al-Suyutisadalah terbagi menjadi empat, yaitu 1) ulama ahli tafsip dari kalangan sahłbat, tabi'in dan tali' al-tabi'in (tiga generasi pertama). 2) Mu'tazilah,

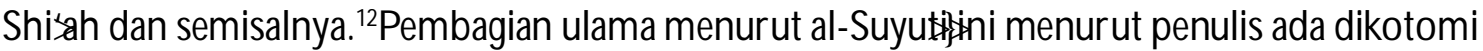
terhadap ulama ahli sumah dan ahli hadith Karena meski ada perbedaan sedikit tentang makna hadth dan sumah dari ulama figh dan ulama usklptapi menurut ulama hạdith, sumah dan hadith adalah sinonim atau mradi ${ }^{13}$

Keenam term ulama menurut Arnold H. G reen adalah corps of reigias leadas kesatuan dari pemimpin agama." Dan dalam penjelasan yang diberikan $G$ reen dalam penjelasanya tentang ulama juga tidak ada batasan ulama itu harus dari kaum laki-laki. ${ }^{14}$

Ketujuh ulama menurut Azyumardi Azra adalah orang yang mengetahui atau orang yang memiliki ilmu. Tidak ada pembatasan ilmu spesifik dalam pengertian ini. Tetapi seiring perkembangan ilmu justru pengertian ulama menyempit menjadi orang yang memiliki pengetahuan dalam bidang fiqh ${ }^{15}$

Keddapan ulama menurut Ali Yafie sebagaimana yang ia kutip dari 'Imad al-D in Ibn Kathis yang menukilkan keterangan dari Ibn 'Abbas adalah bagian dari ulis \&l-amryaitu all alfiqh wa al-din (ahli dalam masalah fiqhdan agama). Sama dengan pendapat Mujakid, 'Atż', al$\mathrm{H}$ \$san al-Bashri dan 'Abu al-'Aliyah (ulama tabi'in). Pengertian ini diperkuat oleh ayat 63 surat al-Maidlah dan ayat 43 surat al-Nahl, ditambahkan dengan hadithsahilhyang diriwayatkan oleh Abu>Hurayrah ra. Dari Nabi saw: "Barangsiapa mendurhakai aku berarti dia sudah mendurhakai Allah dan barangsiapa yang telah mendurhakai amiæ yang telah aku angkat

\footnotetext{
${ }^{9}$ Horikoshi, Kyai danperubahan Sosial (Jakarta: P3M, 1987), 36.

${ }^{10} I b n$ al- Jawzi>TalbisIbis(Kairo: Maktabah al-Madani>1998), 130-151.

${ }^{11}$ al- G hazali>Ihya'XUlumal-Din (K airo: D azal-Sha'b, tt) juz I, 58-82.

${ }^{12}$ Jalakudin al-Suyutip Tábacatal-Mufassinin(Beirut: D azal-Kutub al-Ilmiyah, tt).

${ }^{13}$ Muhammad Z uhri, HadithNabi: TdaahHistonisdanMedoddogis(Yogyakarta: PT. Tiara Wacana, 1997), 1-8. Lihat juga Masfu' Yudi, Pengantar IlmuHadith(Surabaya: Bina Ilmu, 1988), 16.

${ }^{14}$ Arnold H. G reen, TheTunisiaUlama Soial StructureandResponsetoIdedojical Current(Leiden: E.J. B rill, 1978), 3.

${ }^{15}$ A zyumardi Azra, Histariografi, 152-153.
} 
berarti dia telah mendurhakai aku." Penjelasan ini perintah untuk menaati perintah terhadap umara'sdan ulama. ${ }^{16}$

Pengertian ulama yang dijelaskan di atas sama sekali tidak ada yang menyinggung ulama yang dipolakan harus berasal dari jenis kelamin laki-laki atau perempuan, sebagaimana faham marja' dalam Shisah yang mengharuskan dari laki-laki. ${ }^{17}$ Namun praktik anomali dari hal ini juga tetap ada dan tidak menghentikan kontroversi yang terjadi di kalangan al-Fugaha'> tentang peran perempuan dalam beberapa posisi seperti jabatan kehakiman dan pemimpin atau imam yang diqiyaskan dalam peran mengemukakan pendapat dan mengeluarkan fatwa.

Sebagian fugaha’’ Imam Malik, Imam Shafí ìlan Imam Ahinad bin Hąnbal berpendapat bahwa perempuan tidak boleh menduduki jabatan sebagai hakim. A dapun Imam A bu H al-Nu'man berpendapat bahwa boleh saja perempuan menduduki jabatan kehakiman kecuali dalam memutuskan hukuman (hudude) dan qisas sebab tidak ada kesaksian perempuan dalam hal itu. Maka boleh dan tidaknya jabatan kehakiman, menurut Abu»Hąnifah dengan boleh tidaknya memberikan kesaksian. Adapun pendapat yang ketiga adalah pendapat Ibn Jaris al-T \$bari. Ia mengatakan bahwa pada umumnya bahwa perempuan boleh saja menduduki jabatan kehakiman. Hal itu diqiyaskan dengan bolehnya perempuan mengemukakan pendapat dan mengeluarkan fatwa, maka perempuan boleh menduduki jabatan kehakiman. Tidak ada teks yang melarang perempuan menduduki jabatan kehakiman. Berdasarkan hadth mitavatip dari 'Aishah ra. tentang perang Jamal. Ia memimpin pasukan dan mengobarkan revolusi melawan Ali ra, padahal bersamanya juga ada sahabat-sahabat terbaik seperti $\mathrm{T}$ фllhąh, Zubayr dan anaknya Abdullah. ${ }^{18}$

Berkaitan dengan imam słlat, para Fuqaha’juga terjadi kontroversi tentang boleh tidaknya perempuan jadi imam sł̧lat. Menurut pendapat Imam Shafi'i i>perempuan hanya dapat menjadi imam sł̣lat bagi kaum sejenisnya. D asar yang dikemukakan adalah tidak adanya teladan dari generasi awal Islam (Sahabat dan Tabi'in) yang membolehkan perempuan menjadi imam słlat bagi laki-laki. Di samping itu mereka menggunakan argumentasi bahwa aturan yang ditetapkan oleh Nabi untuk sł̧lat jama'ah agar perempuan menempati tempat di belakanng laki-laki. Sementara Abu Thawr dan T \$bariłberpandangan bahwa perempuan boleh menjadi imam sł̣lat untuk perempuan dan laki-laki. Adapun dasar yang digunakan Abu Thawr dan T \$bariæadalah hadith yang menyebutkan bahwa Nabi telah membolehkan Ummu Waraqah, seorang sahabat perempuan untuk menjadi imam sąlat untuk penghuni rumahnya. ${ }^{19} \mathrm{H}$ didith tersebut ada yang menilai dáif dan AbuঙD awud menilai hasan Sedang menurut Ibn H\&izaymah dianggap sabih ${ }^{20}$

\section{Tawaran Dekonstruksi Fiqh Patriarki}

Kaum feminis muslim mempunyai corak tersendiri dalam penafsiran al-Q ur'an ${ }^{21} \mathrm{Hal}$

\footnotetext{
${ }^{16}$ Ali Yafie, "Pengertian Wali al-Amr dan Problematika Hubungan Ulama dan Umara" dalam Nurcholish Madjid, dkk, IsamUnivesal (Yogyakarta: Pustaka Pelajar, 2007), 189-190.

${ }^{17}$ Sholehan," Marja'iyah Taqlid dan Wilayatal-Faøih dalam Syi'ah", Makalah, 2.

${ }^{18}$ Muhammad Anis Q asim Ja'far, al-Hzkquqal-Siyasiyah, 20-21.

${ }^{19}$ Hamim Ilyas, "Rekonstruksi Fiqh Ibadah Perempuan" dalam Wawan Gunawan dan Evi Shofia Inayati (ed.), WacanaFiqhPerempuandalamPerspaktif Muhammadiyah(Yogyakarta: Majelis Tarjih dan UHAMKA, 2005), 6-7. ${ }^{20}$ Nur K hairin, "Perempuan sebagai Imam Shalat" dalam Sri Suhandjati Sukri,(ed) PemahamanIsamdanTantangan KeadlanJender(Yogyakarta: Gama Media, 2002), 103.

${ }^{21} \mathrm{Feminis}$ apologis yaitu yang menggunakan pendekatan filologis dan kontekstual. Penekananya pada mereka
} 
ini muncul karena masih dijumpainya praktik marginalisasi peran perempuan dalam kehidupan sosial agaknya berakar pada budaya patrilineal yang mengedepankan posisi dan peran lakilaki. Faktor utama dari budaya itu diantaranya adalah pemahaman keislaman (figh) yang berwawasan sempit, sehinggajarang perempuan disimbolkan sebagai penguasa, hakim, ulama, pejuang dll. Pemahaman figh tersebut rasanya menyeleweng dari semangat al-Q ur'an yang cenderung memberikan penghargaan positif kepada kaum perempuan.

Al-Q ur'an sendiri secara umum mengidealkan perempuan sebagai sosok yang memiliki kemandirian politik (al-Mumtahł̧nah:12), sebagaimana sosok Ratu Balqis yang mempunyai kerajaan super power (al-Naml; 23), memiliki kemandirian dalam menentukan pilihan-pilihan pribadi (al-Tah jim: 11), perempuan dibenarkan untuk menyuarakan kebenaran dan melakukan gerakan oposisi terhadap berbagai kebobrokan (al-Tawbah: 71), bahkan al-Q ur'an juga menyerukan perang terhadap suatu negeri yang menindas perempuan (al-Nisas. 5). ${ }^{22}$

Di samping itu Masdar Farid Mas'udi juga melihat dalam kitab fiqh klasik masih dijumpai bias anti perempuan atau bias jender. Pemahaman fiqh yang tidak egaliter ini mengundang reaksi H.A.R. G ibb dalam buku Modem Trendin Idamyang menyatakan bahwa hukum fiqh mengenai perempuan kurang mencerminkan semangat al-Q ur'an. Hukum itu hanya didasarkan pada hądith-hł্dith yang mencerminkan tradisi suku Arab saja. Padahal al-Q ur'a hampir setiap hukum mengenai perempuan lewat pemberian hak dan status yang menguntungkan... ${ }^{23}$

Asghar Ali Engineer mensinyalir adanya praktek patriarki dalam Islam itu juga akibat alasan teologis bahwa perempuan diciptakan lebih rendah dari laki-laki. Ia mengusulkan agar tidak menafsirkan yang lepas dari konteks sosial. Seyogyanya penafsiran itu digunakan pendekatan sosio-teologis sesuai dengan ayat al-Qur'an itu sendiri yang amat kontekstual selain harus normatif yang menginginkan keterlibatan perempuan dalam segala aspek kehidupan. Artinya penafsiran saat itu dilakukan realitas sosio klasik yang memang amat sederhana dan tidak banyak tuntutan yang harus melibatkan peran perempuan. D an demkian struktur sosial zaman Nabi tidak benar-benar mengakui kesejajaran laki-laki dan perempuan. ${ }^{24}$

Seperti halnya larangan perempuan menjadi pemimpin atau ulama atau imam sąlat itu didasarkan pada dalil-dalil umum bahwa "al-Rijał Q awwamun 'ala>al-Nisa²5 dan hł̆dith

bukan pada upaya menafsirkan kembali ayat-ayat al-Qur'an agar berdampak kepada dua jenis kelamin, namun dengan mendidik makna dan tafsiran teks-teks tersebut. Feminis Reformis yang menurutya teks-teks keagamaan tentang gender telah difahami secara tidak memadahi, sehingga teks keagamaan harus ditafsirkan secaraliteral. Feminis transformasionis yang berusaha tetap dengan hermeneutika klasik, namun dirumuskan dengan rumusanrumusan yang baru. Feminis Rasionalis yang berasaskan keadilan yang tertata dalam teks-teks yang bersifat kontekstual dan norma-norma etis. D engan metodologi hermenutika kontekstual. Feminis rejeksionis yang mengakui bahwa teks-eks al-Qur'an maupun al-Hditith ada yang bersifat missoginis, seksis dan diskriminatif. D an itu harus ditolak dan merevisi. Feminis posmodernis yang beranggapan bahwa tidak ada "cerita besar" bahwa perempuan itu sub ordinat dan laki-laki itu super ordinat. O leh karena itu perlu dekontruksi bentuk sentralisme itu dengan teologi kesetaraan jender dihadapan Allah yang dikonstruksikan dengan pandangan yang berbeda. Lihat G hazali Anwar, "Wacana Teologis Feminis Muslim” WacanaTedogsFeminis ed. Zakiyyudin Baidawi (Yogyakarta: Pustaka Pelajar, 1996), 3-16.

22Zubaedi, IsamBenturan, 225.

${ }^{23}$ Ibid.

${ }^{24}$ Ibid., 227.

${ }^{25}$ Menurut Nasarrudin Umar kata 'al-Rijak' dalam ayat tersebut lebih ditekankan pada aspek jender laki-laki (maskulinitas) bukan pada jenis kelamin. D an ayat ini terkait dengan kepemimpinan dalam rumah tangga, bukan dalam pengertian umum. Lihat Nasarrudin Umar, Argumen Kestaraan Jender: Pespaktif al-Qur'an (Jakarta: 
tentang larangan perempuan menjadi pemimpin "tidak akan bahagia suatu kaum jika urusannya diserahkan pada kaum perempuan. Hđdith ini diriwayatkan oleh Ibn Majah dan hădith ini tidak berhasil dilacak dalam kitab-kitab standar, baik melalui Mưjamal-Mufahlas sampai pada CD hąditth sehingga tidak bisa dibahas sanadnya. Satu-satunya sumber hądith tersebut ada di kitab Bulugh al-Maram hạdith nomor 437 dan kitab Sharah Subul al-Salam Menurut kitab ini ha्gdith tersebut dajif karena ada salah satu perawinya Abdullah bin Muhammad al-Adaw dari 'Ali bin Zayd bin Jad'an yang dinilai oleh Waki' da'if Pada jalur lain terdapat pula Abd al-Mulk bin $\mathrm{H} \not b i b$ yang sering mencampuradukkan sanad ${ }^{26} \mathrm{D}$ ari deskripsi seperti inilah perlu adanya dekonstruksi fiqh patriarki dengan pendekatan sosioteologis. ${ }^{27}$

Metodologi sosio-teologis ini dipilih minimal karena dua alasan. Petama, sebagaimana

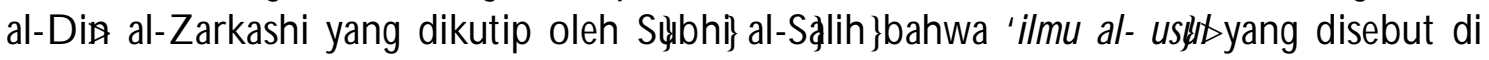
dalamnya oleh al-Zarkashi termasuk ilmu Kalam (teologi) adalah 'ilmm nady wa maihtaraq yang mempunyai maksud sebagai ilmu yang sudah matang dan tidak terbakar. Meski dua kata (nadj dan ihtaraq) ini sangat interpreable namun bagi al-Zarkashi bisa dipahami bahwa teologi Islam adalah ilmu yang sudah matang dan masih bisa dikembangkan. ${ }^{28}$ Bahkan dalam perkembangan terakhir al-Jabiri> teologi Islam dimasukkan dalam kelompok epistemologi bayari $>{ }^{29}$ Sebagimana Amin Abdullah yang juga mengkelompokkan teologi Islam dalam epistemologi nalar bayari>Seandainya bisa difahami dengan pendapat al-Zarkashi, maka teologi Islam menurut al-jabiri tadi bisa difahami sebagai ilmu yang belum matang dan masih sangat bisa dikembangkan oleh para ilmuwan.

Sebagaimana dikatakan oleh ilmuwan Jujun S. Suriyasumantri ${ }^{30}$ bahwa ilmuwan itu mempunyai tanggungjawab sosial. Bukan saja karena dia adalah warga masyarakat, namun yang pasti dia juga mempunyai fungsi tertentu dalam kelangsungan dan pemecahan masalah dalam masyarakat. D engan demikian siapapun ilmuwan dan di era kapanpun mereka hidup, maka mereka syah-syah saja untuk mencurigai teologi Islam dan permasalahanya. ${ }^{31}$

Paramadina, 1999), 57. D an Muhammada Abduh juga berkomentar bahwa surat al-Nisa'rayat 34 tersebut tidak bisa dijadikan sebagai alasan mutlak berada ditangan laki-laki. Hal ini senada dengan apa yang dikatakan oleh Zeenath K ausar. Lihat Z eenath K ausar, Womanas TheHed of StateinIdam?: A study of FewPositiveandNegative Arguments(Kuala Lumpur: ILMIAH PUBLISHERS SD N. BHD. 2002), 28-39.

${ }^{26}$ Nur K hairin, "Perempuan, 102-103.

${ }^{27}$ Barangkali alasan penulis menggunakan istilah sosio-teologis ini hampir sama dengan apa yang dikatakan oleh Surur. Jadi untuk menelaah sebuah sistem pemikiran, sah-sah saja bagi seseorang peneliti untuk menggunakan suatu pendekatan tertentu. Pemikiran teologi atau kalammisalnya tidak saja didekati dengan paradigma ansich melainkan juga dapat dihampiri melalui perspektif sosial, politik, budaya bahkan ekonomi. Barangkali disinilah letak konvergensi antar disiplin ilmu, antara sosial, humaniora dan kealaman. Lihat Surur-Iyunk, Bahrus, Tedog Amal Saldr Merbongkar Nalar KalamMuhammadyahKontemporer(Surabaya: LPAM, 2005), 11.

${ }^{28}$ Lebih detailnya ucapan Badr al-D in al-Zarkashi ini sebagai berikut:al-'ulumthalabah; Tlmnadi wa maihforaquahuw

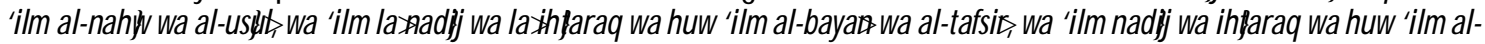
fiqhwaal-hadith". Artinya bahwailmu itu ada tiga yaitu ilmu yang matang dan tidak terbakar adalah ilmu nahydan ilmu uskls, dan ilmu yang tidak matang serta tidak terbakar adalah ilmu bayandan tafsirdan ilmu yang telah matang

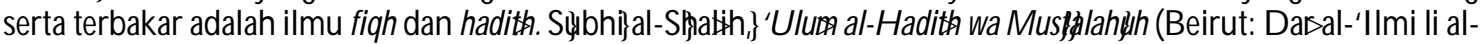
Malayin, 1988, 315).

${ }^{29}$ Y usuf Suyono, Refomasi Tedø̈ MuhammadAbouhuisa usisMuhammadIqbal (Semarang: RaSAIL Media Group, 2008), 212.

30Jujun S. Suriasumantri,FilsafatIlmt: SeauahPengantarPopuler(Jakarta: Pustaka Sinar Harapan, 1990), 237.

${ }^{31}$ Sebagai perbandingan bahwa ada tiga variasi menurut K oento Wibisono dalam hal pengembangan atau "curiga" ( =penulis) terhadap ilmu yaitu petama, ilmu berkembang dalam otonomi dan tertutup, dalam arti pengaruh 
Oleh karena itu teologi tidak lagi membicarakan tentang "Tuhan" murni apa adanya saja, tetapi ilmu uslibal-din yang menawarkan konsepsi-konsepsi tentang alam dan motifmotif untuk bertindak. Artinya teologi tidak hanya memerlukan pijakan dasar akaliahrasional, melainkan juga pijakan dasar kenyataan. ${ }^{32}$ Tawhidharus dikaitkan dengan perbuatan; dari Tuhan menuju bumi; dari dzat Tuhan menuju kepribadian manusia; nilai-nilai kemanusiaan diderivasi dari sifat-sifat Tuhan; dari kekuasaan Tuhan menuju kemampuan berpikir manusia; dari keabadian Tuhan menuju gerakan waktu (sejarah) dan dari eskatologi menuju futurologi. ${ }^{33}$ Dari sinilah teologi Islam pada gilirannya akan memberi perubahan pada berbagai sistem dalam masyarakat; 1) nalar, amal, pemikiran praksis sosial, 2) tawhijd dan konstelasi politik nasional, 3) tawhiddan keadilan sosial-ekonomi, 4) tanhijddan hubungan umat beragama ${ }^{34} \mathrm{D}$ an dalam hal ini, tawhid dan keadilan sosial menjadi bidikan untuk kesetaraan gender.

Argumentasi kedua, munculnya diskursus gender adalah karena adanya konstruksi sosial yang berakibat pada marginalisasi (baca: terhadap kaum perempuan), dan konstruksi sosial yang demikian ini diakibatkan salah satunya adalah faktor para pengiterpretasi terhadap teks agama terutama pada teks-teks yang bersifat misogini (teks-teks yang tidak memihak perempuan) yang masih menimbulkan pemahaman patrilineal (fiqhpatriarki), sehingga perlu adanya dekonstruksi fiqh patriarki yang berpijak pada tawhijd dan keadilan sosial.

Tawhid adalah payung utama ajaran Islam dan merupakan konsep pokok yang lain dalam teologi Islam. Tawhidbukan berarti keesaan Tuhan. D alam teologi pembebasan menurut Ali Engineer, di samping punya makna keesaan Tuhan, tetapi tawhidjuga sebagai kesatuan manusia (unity of mankind) yang tidak akan benar-benar terwujud tanpa terciptanya masyarakat tanpa kelas (dasses soiey). Konsep tamhid ini sangat dekat dengan semangat alQ ur'an untuk menciptakan keadilan dan kebaikan (al-'ad wa al-ahsan). ${ }^{35}$

Menurut Nur Cholis Madjid kata "iman" mempunyai akar yang sama dengan "aman" (Arab: aman yakni kesejahteraan dan kesantausaan) dan "amanat" (Arab: amamah yakni keadaan bisa dipercaya atau diandalkan (Inggris: trustwathinmess) lawan dari khianat. Oleh karrena itu "iman" yang membawa rasa "aman" dan membuat orang mempunyai "amanat". D engan inilah "iman" tanpa konsekuensi yang nyata bisa tak bermakna atau absurd Dan salah satu wujud asal "iman" adalah sikap hidup yang memandang Tuhan sebagai tempat menyandarkan diri dan menggantungkan harapan. O leh karena itu konsistensi "iman" adalah hlusn al-żam dan optimis kepada Tuhan serta kemantapan kepadaNya sebagai Yang Maha Kasih dan Maha Sayang, di samping pengetahuan-Nya adalah sifat Tuhan yang paling

konteks dibatasi bahkan disingkirkan (siencefor thesakeof saieneanly). Keelua, ilmu lebur dalam konteks, tidak hanya memberikan refleksi tapi juga memberikan justifikasi. D engan ini ilmu memasuki wilayah yang ingin menjadikan ilmu sebagai ideologi. Ktiga, ilmu dan konteks saling melengkapi dan mempengaruhi untuk menjaga agar dirinya dan temuan-temuanya tidak terjebak dalam kemiskinan relevansi dan aktualitasnya (sierefor thesake of human progress). D an menurut penulis pengembangan ilmu Kalam bisa dilakukan tetap dalam tiga variasi ini. Lihat Koento Wibisono Siswomihardjo "Hubungan Filsafat, Ilmu dan Budaya", Makalah, disampaikan pada matakuliah umum di Semarang, 2001, 13.

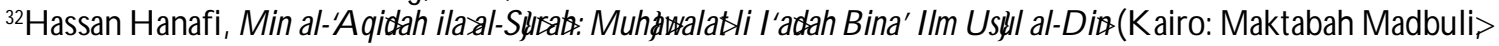
tth), Vol. I, 32-37.

${ }^{33}$ Hassan Hanafi, IdaminTheModenWord Reigion IdkdogyandDexdopment(Kairo:The Anglo-E gyption Bookshop, th), Vol. I, 8-14.

${ }^{34}$ Ibid., 35-36.

${ }^{35}$ Asghar Ali E ngineer, Isamdan Tedoj Pembebasan (terj.), Agung Prihantoro (Yogyakarta: Pustaka Pelajar), 11. 
komprehensif dan serba meliputi. ${ }^{36}$

Berkaitan dengan dekonstruksi fiqhpatriarki yang berpijak pada asas tawhiddan keadilan sosial, penulis melihat bahwa Islam memberi peluang yang sama antara laki-laki dan perempuan untuk beramal saleh dan Tuhanpun tidak menyia-nyiakan amal saleh tersebut. D an semua itu tercantum dalam teks-Nya al-Q ur'an 9 (al-Tawbah): 71, 16 (al-Nahl): 97, 3 (A k- Imran): 195. D engan demikian sebagai konsekwensi "iman" serta "tawhije" maka tidak ada lagi alasan untuk membatasi laki-laki dan perempuan bahkan membedakannya dalam menjalankan 'amanat'nya untuk beramal saleh. Kalaupun laki-laki bisa menduduki posisi dan berperan sebagai "ulama", maka perempuanpun demikian. D an itulah keadilan Tuhan yang diberikan kepada hambaNya.

Memang terjadi kontroversi antara para penginterpretasi agama (sebut: para fugaha'ł untuk menentukan boleh dan tidakbolehnya implikasi perempuan untuk posisi dan peran mereka dalam kepemimpinan, hakim, atau kalau boleh sebut saja ulama ${ }^{37}$ sebagaimana penjelasan di atas. Di antaranya para pengiterpretasi masih bias gender untuk memahami teks-teks agama yang bersifat misogini karena perspektif patrilinial ${ }^{38} \mathrm{D}$ an ini semua di antaranya karena alasan teologis sebagaimana yang dikatakan Ali Engineer. Maka dari itu penulis menawarkan pula dekonstruksi epistem hukum Islam terutama pada fiqh patriarki yang berpijak pada teologis.

Untuk melakukan dekonstruksi epistemologi hukum Islam, seseorang harus melakukan 'pembacaan ulang" atau i'adat al-qiraah terlebih dahulu atas nama fenomena "fakta Q ur'an" dan "fakta Islam" yang melahirkan formulasi hukum Islam klassik-skolastik. Pembacaan ulang tersebut penting dilakukan untuk mengetahui sebab-sebab yang melatarbelakangi kelahiran formulasi hukum tersebut. ${ }^{39}$ Pertama-tama, pembacaan itu berkaitan dengan fakta Qư'ari>sebab Quranmerupakan titik tolak yang utama dalam studi sejarah kritis pemikiran Islam-Arab untuk memahami bagaimana dunia Islam dilihat seperti apa adanya sekarang ini. Masalah umumnya berkaitan dengan interaksi antara wahyu, kebenaran dan sejarah yang berlangsung sejak tahun $622 \mathrm{M}$ hingga sekarang. ${ }^{40}$

Itu adalah konsep Arkoun. Melalui pembacaan ulang (i'adat al-qira'ah) Arkoun ingin mendialogkan kedua pendekatan tersebut secara proporsional. D engan kata lain ia ingin menekankan orientasi kontekstualitas dan historis atas wahyu tanpa melupakan tekstualitas dan normatifitas wahyu tersebut. ${ }^{41}$ Dalam kritik ini ia menawarkan empat analisis dalam

\footnotetext{
${ }^{36}$ Nurcholish Madjid, IsamDdktrindan Peradaban: SearahTdaah KritistentangMasalahKeimanan, Kemanusiaandan Kemodkenan(Jakarta: Paramadina, 1992), 94-95.

${ }^{37}$ Posisi dan peran ulama dalam hal ini penulis sejajarkan dengan posisi dan peran "pemimpin" dan "hakim" meski tidak menyeluruh bahkan terjadi pro kontra karena ulama adalah orang yang meminpin umat dan yang mempunyai peran untuk memberi fatwa (Lihat kembali penjelasan ulama yang dihadirkan penulis dari berbagai perspektif pada hal. 17-19),

${ }^{38}$ Pernyataan penulis dalam posisi dan peran ulama perempuan yang masih bias gender ini juga diperkuat Zubaedi dan lain-lain. Lihat Z ubaedi, IsamBenturan, 224-225. Bahkan dalam waktu yang tidak lama,disinyalir Farid dalam makalah minimnya keterlibatan perempuan di ulama zaman dulu itu karena kemampuan perempuan yang masih terbatas. Lihat M. Farid Zaini “Ulama Perempuan: Antara Propaganda gender dan Fakta Sejarah”, Makalah yang disiskusikan pada 5 Januari 2009 dalam matakuliah Istitusi Ulama, 2.

${ }^{39} \mathrm{Amin}$ Abdullah, "Muhammed Arkoun dan Kritik Nalar Islam" dalam Johan HendrikMeuleman (ed.), Islam Trdis Modkmismedan Memodamisme MempedincangkanPemikiranMuhammaedArkan(Yogyakarta: LKiS, 1996) ${ }^{40}$ Mohammed arkoun, PerikiranArab terj. Yudian W. Asmin (Yogyakarta: Pustaka pelajar, 1996), 139.

"11lyas Supena dan M. Fauzi, Dkkonstruksi danRkonstruksiHukumIsam(Semarang: G ama Media, 2002), 126.
} 
memahami al-dkhirah al-Qur'aniyah (fakta Q ur'ani) dan al-dkkirah al-islamiyah (fakta Islami) yaitu: analisis historis, antropologis, sosiologis yang ketiganya itu berorientasi pada konteks, serta analisis linguistik (hermeneuitika dan semiotik) yang berorientasi pada tekstualitas dan normativitas wahyu. ${ }^{42}$

Melalui empat analisis itu, teks-teks agama tentang perempuan dapat dibaca secara lebih terbuka dan objektif, seperti hadithmisogini (yang isinya membenci kaum perempuan) atau teks Q ur'an yang membahas tentang superioritas laki-laki. ${ }^{43}$ Contoh hadith misogini adalah yang disebutkan al-Buhł̧æ dari AbußBakrah:

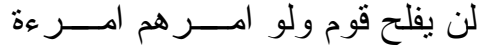

"Siapa yangmenerahkan unusanya kepada kaumperempuan, medka tickk akan mendapatkan kemakmiran"

Adapun usaha pembacaan ulang terhadap hądith tentang kepengurusan perempuan sebagai fakta Q ur'ani bisa berpijak pada Q S: 9 (al-Tawbah): 7 yang mengemukakan bahwa laki-laki dan perempuan memiliki kewajiban melakukan kerjasama dalam berbagai bidang kehidupan, termasuk bidang politik. Begitu halnya dalam Q S: 4 (al-Nisas): 124 yang menyebutkan bahwa Allah telah menciptakan laki-laki dan perempuan memiliki kemampuan yang sama untuk mengerjakan amal-amal saleh dalam berbagai segi kehidupan. D an mereka akan mendapatkan hasil atau balasan yang sama. D alam ayat tersebut tampak jelas bahwa Islam memilki konsep keadilan jender dan tidak mengenal diskriminasi.

Sementara itu analisis fakta Islami (maksudnya analisis historis, antropologis, sosiologis) dalam usaha pembacaan ulang terhadap hadith tentang kepengurusan atau kepemimpinan perempuan dapat disampaikan sebagai berikut.

Petama, sesuai dengan analisis historis hądith tersebut di atas terdapat dalam Musnad Ahhrad Hanbal (juz V), Słalih al-Bukhariłjuz IV) dan al-Nasa'ił łjuz IV). Hadith itu oleh alG hazali>dalam kitabnya al-Sumah al-Nabaniyah bayn al-Figh wa al-Hadith dinilai sahhih dari sisi matan, sedangkan dari sisi sanadnya adalah hạdith ahadyang sebagian orang meragukan autentitasnya. Namun perlu digarisbawahi bahwa hadith itu merupakan komentar Nabi atas situasi yang terjadi di Persia. Jadi tidak bisa diperlakukan secara umum. ${ }^{44}$

${ }^{42}$ Menurut Amin Abdullah analisis anthropologi dalam teologi Islam semestinya tidak masuk dalam wilayah hightraditionyakni wilayah gugusan teori, konsep, ide, keberagaman dalam budaya tradisi literer. Lihat M. A min Abdullah, "Pendekatan Teologis" dalam Kelompok Studi Lingkaran, (ed), Intddktualisme, yang ditulis Juli 1989 di Yogyakarta. Sedangkan pembacaan semiotik dan linguistik atas wahyu yang berbentuk kanon resmi tertutup (the offisial dased canons) yang kemudian diperkaya dan diperluas dengan perkembangan politik, kultural, dan anthropologi sosial akan melahirkan definisi baru tentang mitos, rasionalitas, rasonyang berhubungan dengan konsep "imajinasi" yang ilmiah terbuka. Hal ini akan menghilangkan kesan interpretasi reduktionis terhadap yang sakral. Lihat Ilyas Supena dan M. Fauzi, Dekonstruksi dan RdkonstruksiHukumIsam(Semarang: G ama Media, 2002),128-129.

${ }^{43}$ Minimal ada empat hädith misogini yaitu tentang "siapa yang menyerahkan urusannya kepada perempuan, mereka tidak mendapatkan kemakmuran", "Anjing, keledai dan perempuan akan membatalkan shalat jika melintasi di antara orang yang shalat dan kiblat", "ada tiga hal yang membawa bencana yakni rumah, perempuan dan kuda, "sepeninggalku kelak tidak ada penyebab kesulitan yang lebih fatal bagi laki-laki kecuali perempua" dan "aku melihat ke surga dan aku saksikan sebagian besar penghuninya adalah kaum miskin, dan aku lihat ke neraka, aku saksikan sebagian besarpenghuninya adalah kaum perempuan". Lihat Fatimah Mernissi, WanitaDalamIdam(ter) Yaziar Radiantrti (Bandung: Pustaka, 1994), 62, 83, 98,97. Lihat juga Słabihbal-Bukhaki, vol. IV, 236, 99, 243, 137 atau lihat Ibn Hajjr al-A sqalani>Fath,al-Barifi Sharh,al-Bukhari, juz XIII (Ttp, Maktabah salafiyah, tt), 53, 585, 137. ${ }^{44}$ Sri Suhandjati Syukri, "Perempuan Sebagai Kepala Negara" dalam dalam Sri Suhandjati Sukri (Ed.), Pemahaman Isam 116 . 
D ari segi perawi hądith̆, memilki sifat dapat dipercaya, dan dalam menuturkan hạdith itu dengan penerimanya (mata rantai perawinya bersambung atau pernah bertemu). Hadith tersebut diriwayatkan oleh Abu Bakrah saja dan diturunkan kepada dua orang, yaitu Abdur Rahman bin Jausan (menantunya) dan al-Hasan.

Keelua, analisis sosiologisnya adalah bahwa peristiwa yang melatarbelakangi lahirnya hagdith tersebut adalah wafatnya Kisra Persia dan diangkatnya anak perempuannya yang bernama Buran menggantikan Ayahnya. Kerajaan Persia saat itu sedang dihadapkan pada tantangan yang berat, yaitu kerajaan Romawi yang menyerbu wilayah Persia dan berhasil menguasai beberapa daerah. Di samping situasi kerajaan yang kacau, diperkirakan Buran tidak memiliki kemampuan untuk memimpin kerajaan besar seperti Persia.

Penuturan tentang kondisi Persia itu disampaikan oleh Abdullah bin Hadhafah yang baru pulang dari Persia. Ketika mendengar berita itu, Rasulullah mengomentari melalui sabdanya tersebut di atas. Di sini terlihat adanya peristiwa tertentu yang menyebabkan lahirnya hädith tersebut. D engan demikian, apabila dihubungkan dengan hal ini, sabda Rasulullah tersebut tidak berlaku untuk perempuan umum tetapi kondisional.

Ketiga, secara antropologis ${ }^{45}$ bisa dikatakan bahwa sistem pengetahuan Abu>Bakrah sebagai seorang budak yang mendapatkan kemerdekaan setelah masuk Islam masih sulit untuk memilih salah satu dari orang-orang yang dicintai Rasulullah yang sedang terlibat konflik tersebut. $\mathrm{H}$ didith yang melarang seperti riwayat Abu>Bakrah itu disampaikan oleh Abu>Bakrah sewaktu ia menghadapi situasi yang sulit karena harus memilih antara mendukung 'Ali atau 'Aishah yang pada waktu itu terlibat konflik yang berpangkal pada terbunuhnya Uthman bin 'Affan. Konflik itu memuncak dengan terjadinya perang Jamal. Akhirnya Abu×Bakrah cenderung memihak kepada Ali bin Abi T alib yang pada waktu itu berhasil mengalahkan 'Aishah dan menguasai kota Basrah. D alam kondisi seperti itu Bakrah mengungkap hądith tersebut. D engan demkian dapat difahami bahwa hădith itu tidak berlaku umum dan pemunculannyapun diwarnai oleh kepentingan tertentu.

D engan usaha dekonstruksi seperti ini, mungkin bisa menghasilkan suatu pemahaman yang dikehendaki (fiqh). Paradigma teologis yang tepat dan responsif ini bisa dikatakan sebagai usaha penyegaran wawasan ideologi. ${ }^{46}$ Maka lewat cara ini, perempuan juga berhak memperoleh peluang untuk memerankan dan memosisikan diri mereka setara dengan lakilaki, baik sebagai pemimpin, hakim, ulama dan lain-lain. Wa Allah al-A lambi al-Săvaba

\footnotetext{
${ }^{45}$ Penulis dalam menganalisa secara antropologis ini, melihat antropologis budayayang mengkaji manusia dalam dimensi kebudayaan yang dimilikinya baik yang menyangkut bahasa, tulisan, kesenian, sistem pengetahuan dan totalitas kehidupan manusia. Lihat Nur Syam, MadzhabMadzhabAntropdogi(Yogyakarta: LkiS, 2007), 4-5. ${ }^{46} \mathrm{D}$ alam pengertian yang umum ideologi dapat difahami sebagai keseluruhan prinsip atau norma yang berlaku dalam masyarakat yang meliputi sebagai aspek seperti sosial, politik, ekonomi, budaya dan hukum. Ideologi juga dapat difahami sebagai prinsip-prinsip yanng mendasar tingkah laku seseorang atau kelompok dalam kehidupan dalam bermasyarakat dan bernegara. Ideologi dalam hal ini sebagai sistem paham, suatu perangkat pemikiran yang menyeluruh yang bercita-cita menjelaskan wajah dunia. Lihat M. Sastrapraterdja," D ari Utopia ke Ideologi dari Ideologi ke Aksi dan Refleksi, dalam PrismaI, Januari 1982, 5-6. Sedangkan menurut Karl Manheim ideologi adalah ramalan tentang masa depan yang didasarkan pada sistem yang sekarang sedang berlaku. Lihat $\mathrm{K}$ arl Manheim, Idedog andUtopia(New York: International Library, 1936), 55-59.
} 


\section{Daftar Rujukan}

Abdullah, Amin. "Muhammed Arkoun dan Kritik Nalar Islam" dalam Johan Hendrik Meuleman (ed.). IsamTradsi Modknismedan Metmodemisme Mempedincangkan Perikiran Muhammaed Arkain Yogyakarta: LKiS, 1996.

Amin, Q asim. Tahliz al-Mar'ah wa al-Mar'ah al-Jadidh Kairo: al-Markaz al-'Arabiyah, 1984. Anwar, G hazali. "Wacana Teologis Feminis Muslim," dalam Wacana Tedogs Feninis, ed. Baidawi, Zakiyyudin. Yogyakarta: Pustaka Pelajar, 1996.

Arkoun, Mohammed. Perikiran Arab terj. Yudian W. Asmin. Yogyakarta: Pustaka pelajar, 1996.

al-Asqalany, Ibn Hạjs, Fath/al-Bahł fi Sharh/al- Bukhari, juz XIII. Ttp, Maktabah Salafiyah, tt. Ash-Sijddiey, T.M. Hasbi. Lapangan Pejuangan Wanita IsamY ogyakarta: Menara kudus, 1952. Azra, A zyumardi. Histariogafi IslamKontemporer: Wacana, Aktualitas danA Aktor Sejarah Jakarta: PT. Gramedia Pustaka Utama, 2004.

Engineer, Asghar Ali. Idam dan Tedog Penbdbasan (terj.), Agung Prihantoro. Yogyakarta: Pustaka Pelajar, 2003. . Penbebasan Perempuan (terj.) Agus Nuryanto dari “The Q ur'an Women and Modern Society". Yogyakarta: LkiS, 1999.

Beck, Lois dan Nikki Keddie. Womm in the MusimWorld Cambridge: Harvard University Press, 1980.

Burhanudin dkk, Jajat. Ulama Perempuan Indonesia Jakarta: PT. Gramedia Pustaka Utama, 2002.

al-Banna, H\$san. al-Mar'ah al-Musimah Kairo: al-Maktabah al-Sunnah, tt.

Chalil, Munawar. Nilai Wanita Semarang: C.V Ramadhani, 1969.

al- G hazali> Ihyja' Ulumal-Din K airo: D as al-Sha'b, tt.

G reen, Arnold H. TheTunisia Ulame Social Structureand Responseto Idedogical Current. Leiden: E.J. Brill, 1978.

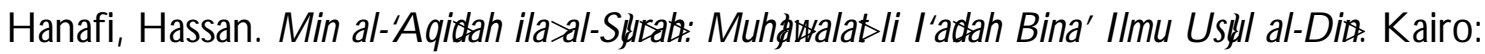
Maktabah Madbuli>tth, Vol. I. Idam in The Modem Wodd Reigion Idedogy and Deddqument. Kairo: The AngloEgyption Bookshop, tth, Vol. I.

Horikoshi, Horikoshi. Kyai dan peubahan Sosial. Jakarta: P3M, 1987.

Ilyas, Hamim. "Rekonstruksi Fiqh Ibadah Perempuan" dalam Wawan G unawan dan Evi Shofia Inayati (ed.). Wacana FiqhPerempuandalamPespektif Muhammadiyah Yogyakarta: Majelis Tarjh dan UHAMKA, 2005.

Ismanto, Jumari. Peranan Wanita dalam Pendbangunan Bangsa Menunt Isam Surabaya: Bina Ilmu,1982.

Jaelani, Abd Kadir. PeranUlama dan Santri dalamPejuanganPditik Isamdi Indonesia Surabaya: Bina Ilmu, 1994.

al- Jawzi>Ibn. Talbis Idis. K airo: Maktabah al-Madani>1998.

Ja'far, Muhammad Anis Q asim. Perempran dan Kdkuasaan: Mendusun Hal Pditik dan Pessoalan dalamIsam terj.. Amzah: tp, 2002.

Kausar, Z eenath. Womm as The Heed of Statein Idam?: A sudy of Fen Positive and Negative 
Argumet. Kuala Lumpur: ILMIAH PUBLISHERS SD N. BHD. 2002.

Khairin, Nur. "Perempuan sebagai Imam Shalat" dalam Sri Suhandjati Sukri,(ed) Pemahaman Islam dan Tantangan Keadilan Jender. Yogyakarta: G ama Media, 2002. Manheim, Karl. Idedog and Utopia New York: International Library, 1936. Mernissi, Fatimah.Wanita dalam Islam (te) Yaziar Radiantrti. Bandung: Pustaka, 1994. Mutahhari, Morteza. Wanita dan Hak-Haknya DalamIsam Bandung : Pustaka, 1986. Nakamura, Mitsuo. "Muhammadiyah: G erakan Islam Yang Kokoh", wawancara dalam Meeia Inovas, No. 11, Tahun VI, D esember 1994.

Ridla, Muhammad Rashid. Panggilan Idam tehadap Wanita. Bandung: Pustaka, 1986. Salman, Ismah. "Keluarga Sakinah" dalam 'Aisyah: Diskursus Gender d Qrganisasi Perempuan Muhammadiyah .Jakarta: PSAP Muhammadiyah, 2005.

Shuqqah, Abdul Halim Abu. Tahlizal-Mar'ah fi`Asł' al-Risalah Kuwait: D ał al-Q alam ,1998. Syam, Nur. Madkhab-Madkhab Antropdog. Yogyakarta: LkiS, 2007.

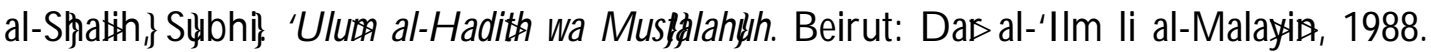

Sharma, A rvind. Wommin theWoddReigiondalam PerempuandalamAgama Duria, al-Mirzanah, Syafaatun dkk (terj). Jakarta: D epag RI dan CIDA-McG ill-Project, 2002.

Shihab, Q uraish. Pean peempuan menunt Isam Jakarta: INIS, 1991.

Siswomihardjo, Koento Wibisono. "Hubungan Filsafat, Ilmu dan Budaya", Makalah disampaikan pada matakuliah umum di Semarang, 2001.

Soekanto, Soerjono. Sosidog Suatu Pengantar. Jakarta: PT Raja Grafindo Persada, 1990. al-Suba4, Mustgafa. al-Mar'ah bayna al-Fiqh wa al-Qamu Kairo: D aßs al-Salam, 1998.

Suriasumantri, Jujun S. Filsafat Ilmr Searah Pengantar Popules. Jakarta: Pustaka Sinar Harapan, 1990.

Surur-Iyunk, Bahrus. Tedog Ambl Saldr Menbangkar Nalar KalamMuhammadiyah Kontempare. Surabaya: LPAM, 2005.

al-Suyutis Jalakudin. Tábacatb al-Mufassinin Beirut: D as al-Kutub al-Ilmiyah, tt.

Supena, Ilyas dan M. Fauzi. Dekonstruksi dan RdkanstruksiHukum Islam Semarang: G ama Media, 2002.

Umar, Nasarrudin. Argumen KestaraanJender: Pespaktif al-Quran Jakarta: Paramadina, 1999. Vitalaya, Aida. Penditian Peran Seta, dalam Penditian Jendar. Jakarta: D epdikbud, 1995. Yudi, Masfu'. Pengantar Ilmu Hadith Surabaya: Bina Ilmu, 1988.

Yafie, Ali, "Pengertian Wali al-Amr dan Problematika Hubungan Ulama dan Umara" dalam Nurcholish Madjid, dkk, Isam Univesal. Yogyakarta: Pustaka Pelajar, 2007. 